International Journal of English Literature and Social Sciences
Vol-7, Issue-1; Jan-Feb, 2022
Journal Home Page Available: $\underline{\text { https://ijels.com/ }}$ Journal DOI: $10.22161 /$ ijels

Peer-Reviewed Journal

\title{
A Symbolic Study of the Poem on Killing a Tree
}

\section{Shivanand Hiremath}

Assistant Professor, Department of English, Government First Grade College, Bengaluru, Karnataka, India

Received: 23 Dec 2021; Received in revised form: 01 Feb 2022; Accepted: 09 Feb 2022; Available online: 17 Feb 2022 C2022 The Author(s). Published by Infogain Publication. This is an open access article under the CC BY license (https://creativecommons.org/licenses/by/4.0/)

\begin{abstract}
The killing of a tree symbolizes deforestation. The perishing of trees is a threat to our environment. A tree has grown to this extent taking a lot of time to grow by absorbing air, water, sunlight and minerals from the earth soil. The roots give energy to the trees. But people kill the trees without any mercy for their instant interests not considering the long-term impacts and as a result, the environment, as well as mankind, suffers. Therefore, we must be mind and soul towards trees and killing of trees must be stopped. If we consider the symbolic meaning of the poem, we will definitely stop thinking at last and finally say that Tree means Social Evils or Socially worst practices. Can we compare Tree to a social Evil? When we want to remove one long practiced custom in the society it will be like well grown up tree, to stop it immediately is impossible, it's not possible to stop after a bit of warning or precautionary measures (A simple jab or knife) Like this a whole poem consists of images and symbols.
\end{abstract}

Keywords- Tree, human body, social evils. cutting a tree, killing a tree, branches, evil practices, relation corruption, terrorism, social fallacy.

\section{INTRODUCTION}

We must have observed people cutting down trees. But can anyone kill a tree? Is it easy to do so? The Poem is written by Gieve Patel. He was born in 1940 in Mumbai. He was educated at St Xavier's High School and Grant Medical College. He lives in Mumbai where he is a general practitioner.

In this poem, instead of 'cutting' a tree the word "killing" is used, which indicates the length and breadth of the destruction and the obstinance of the tragic act. For this, the killer needs to follow a meticulous process. No amount of "hacking and chopping" will be enough as a tree will heal its wound soon. Small twigs will sprout again and will grow slowly to regain its former structure thereby resisting the destruction of a tree.

To stop this, the tree should be uprooted entirely. When the poet says this, he may mean that the social evil practices like inequality to women, corruption, caste system, dowry system, etc are need to be removed from the society entirely but it's not such easy, because as the poet says in the next line that, "As the earth has been acting as its anchor for ages," here earth means the system which posters the worst practices like this. The poet proceeds further with the action need to be taken he says, "It should be separated from the earth. A strong rope must be tied around it, and with its help it should be snapped out from the ground" We may symbolically interpret that the kind of evil practices must be abolished from the interior crust of the society.

\section{THE MAIN BODY}

Literally when we read the poem the great hazard to cut a tree appears simply on the first level reading. It will be quite difficult to cut a tree which has grown fully for the years consuming the water, minerals, air and energy from the surrounded environment. The branches even we cut but grow again. To stop them grow one has to go for the rigorous and vigorous actions.

A tree is man's greatest friend as it helps the latter to sustain, primarily by providing food and oxygen. But man treats it like a foe and kills it ruthlessly to meet their selfish interests. Man does not realize that by killing trees they cause harm to themselves in the long run as it de- 
stroys the ecological balance. The poet builds up the irony by presenting the act of cutting down a tree in the form of an explicit account of killing the same. The mindless act of deforestation is no less than a heinous crime, committed by the greedy and inconsiderate section of mankind. That is why the poet in this poem has made the tree itself receive punishment in the hands of its murderers. This is the irony behind the meticulous act of killing a tree as depicted in the poem.

In the poem 'On Killing a Tree' certain human attributes have been given to the tree. Here the tree has been depicted as a child who after birth, gradually strengthens its position and finds nourishment from nature for itself. The tree takes years to grow slowly consuming the earth, rising out of it and drawing nourishment from it. It spreads its roots and absorbs sunlight, air and water which help it to mature and sprout leaves. The tree is also described as someone who can feel pain and who bleeds when gets a wound. So, the expression, 'bleeding bark' is used to emphasize the human attribute. Again, the roots of the tree are called 'sensitive' that is a typical human quality and if they are snapped out completely, it kills the tree. Moreover, the word "killing" is mostly used in association with a human being. Here, this exceptional use of the word 'killing' makes it evident that the poet has brilliantly given human attributes to the tree that adds to the much valuable impact of the poem.

The relationship of a tree with the earth is almost like a mother-child relationship, which is brought out by Patel in a poetic way in this poem. When a tree is a small sapling the earth gives it shelter. It allows that sapling to spread its roots into the earth and the earth acts as an anchor, thereby securing the tree. Then it nourishes the tree by feeding it with sunlight, air and water. The tree grows up consuming the earth. When it becomes a full-grown tree it tries to look after the world in return. It gives shelter to many birds, it helps human beings as well as other creatures to live by offering a suitable environment, absorbing carbon dioxide, releasing oxygen and also by providing food. Every part of a tree tries to repay the world in every possible way. Thus, an eternal bond exists between the two.

The poet talks about one of the major concerns of modern-day life, which is the destruction of the environment. The poet is sympathetic towards the trees and treats them as living organisms which feel pain and pleasure like human beings. So, the trees should not be deprived of their right to live. Trees help people in a number of ways but people destroy the trees indiscriminately, disregarding the benefits that they get from them. Thus, he uses the images of violence like cutting, jabbing, bleeding to show man's ruthlessness. On the other hand, the poet uses contrasting images of spreading of leaves and boughs to show the endless life of a tree. Thus, the poet describes the killing of a tree in such graphic detail to evoke sympathy towards trees. He wants to convey to his readers that to hurt a tree is similar to hurt a human being as trees are also living organisms who can feel.

\section{CONCLUSION}

After the reading of the poem with different perspectives we find the various symbolic meaning of the poem. The Social Evils are grown with such strength of a huge tree. To kill a tree also symbolizes the human beings ruthless attack on the nature as well. Through many images and symbols one can find the different layers of meaning.

\section{REFERENCES}

[1] English Pearls, (2016) \#Bloomsbury Publications, New Delhi, page number 64-65

[2] English Stars, (2020), RC University, Belagavi,

[3] https://www.poemhunter.com/gieve-patel/biography/

[4] https://www.youtube.com/watch?v=kOeYfbB1pGo

[5] https://brainly.in/question/24931559\#: :text=In\%20this\%20 poem\%20'on\%20killing,turn\%2Cman\%20kills\%20the\%20tree 